N. JU, ${ }^{1}$ SH. Q. LIU, ${ }^{1}$ B. LU, ${ }^{1}$ and X. JIANG ${ }^{1}$

\title{
FIRING PATTERNS OF LEECH HEARTBEAT INTERNEURONS UNDER EXTERNAL CURRENT STIMULATION: A MODEL STUDY
}

\author{
Received May 22, 2014
}

Leech heartbeat interneurons (HN cells) interconnected by inhibitory synapses have been simulated using several modified models based on the Hodgkin-Huxley equations; yet, adequate characteristics of HN cells are hardly possible to be summarized due to the complexity of these models. The Winnerless Competition (WLC) model created as an inhibitory-connected nervous network is more appropriate for networks consisting of HN cells. We investigated different firing patterns produced by such model under application of various stimuli simulating changes in the leech's environment. By means of recording the firing frequency, synchronization, interspike intervals (ISIs), and maxima of action potentials (APs) and also by application of the theory of mixed-mode oscillations (MMOs), different properties of firing patterns in $\mathrm{HN}$ cells were examined. According to the results of computational analyses, DC and AC stimulations were found to play different roles in modulating the leech's heartbeat rhythm; external stimuli could influence the intensity and duration of the network reaction by changing both AP frequency and amplitude. Besides, changes in the recovery abilities of neurons can lead to various release modes of HN cells. Combined with physiological experiments on medical leeches, numerical analysis allows us to gain a deeper understanding of how HN cells coordinate with each other to bring the rhythm to the leech heartbeat system.

Keywords: leech heartbeat interneurons (HN cells), firing patterns, Winnerless Competition (WLC) model, synchronization, interspike intervals (ISIs), mixed-mode oscillations (MMOs).

\section{INTRODUCTION}

Electrical signals in the nervous system are transmitted by action potentials (APs) of neurons; the latter exist in two states, namely resting and firing [1]. Distinct states of AP generation constitute the basic information of brain activities and reflect the regularities of the brain coding system [2]. A series of the experiments have been done to study responses of the nervous system when facing different stimuli, including studies of potentials, firing, and chemical transmission among neurons [3-6]. From this aspect, physiological anatomy is the most elementary method in researching complex processes of information transmission. Along with detailed study, the theory of nonlinear dynamics has been proposed to analyze the inherent relationship between stimulation and responses. Firing patterns of

\footnotetext{
${ }^{1}$ South China University of Technology, Guangzhou, China. Correspondence should be addressed to: Sh. Q. Liu (e-mail: mashqliu@scut.edu.cn).
}

a single neuron can be expressed as a dynamic model, while the status of a neuronal system (network) can be modeled as a group of such dynamic systems.

Heartbeat in the medicinal leech is a continuous spontaneous process [7]. Heart contractions are coordinated by heart excitatory motor neurons (HE cells) situated in the 3 rd through 18 th segmental ganglia, which control the constriction of a pair of bilateral longitudinal blood vessels [1]. Seven pairs of segmental heart interneurons, $\mathrm{HN}(1)$ to $\mathrm{HN}(7)$, are the main units of the heartbeat central pattern generator (CPG), which gives rhythmic coordination to HE cells [8]. HN(1)-HN(4) cells are central to the generation of beat-timing oscillations in the CPG, with $\mathrm{HN}(1)$ and $\mathrm{HN}(2)$ working as coordinative interneurons, which serve to connect two half-center oscillators [9]. Units $\mathrm{HN}(3)$ and $\mathrm{HN}(4)$ as oscillatory interneurons that inhibit a switch heart interneuron, $\mathrm{HN}(5)$ [8], while $\mathrm{HN}(6)$ and $\mathrm{HN}(7)$ cells serve together with $\mathrm{HN}(5)$ in transmitting a coordinative rhythmic input to HE cells, regardless of generating beat oscillations. All synapses 
among HN cells are inhibitory; hence, the network that consists of HN cells is competitive.

In our study, we investigated certain properties of a leech heartbeat timing oscillator that consists of pairs of HN cells, HN(1)-HN(7) [10]; a model closer to actual physiology, when compared to previous models, was used. The Winnerless Competition (WLC) model proposed by Rabinovich [11] is suitable for competitive networks; it performs well in simulating of a number of nervous networks.

\section{METHODS}

Network of Leech Heartbeat Interneurons. We selected a network composed of the first seven pairs of $\mathrm{HN}$ cells from the leech heartbeat CPG. Interneurons are interconnected via inhibitory synapses and a pair of rectifying synapses in this network. To aid the convenience of description, we use here letters from $\mathrm{B}$ to I to mark different $\mathrm{HN}$ cells rather than using symbols like $\mathrm{HN}(3)$, etc., with B standing for $\mathrm{HN}(1)$, C for $\mathrm{HN}(2), \mathrm{D}$ for $\mathrm{HN}(3), \mathrm{E}$ for $\mathrm{HN}(4), \mathrm{F}$ and $\mathrm{G}$ for $\mathrm{HN}(5), \mathrm{H}$ for $\mathrm{HN}(6)$, and I for $\mathrm{HN}(7)$. Detailed connections are shown in Fig.1.

Model of Winnerless Competition. Based on the studies of olfactory processing in insects and fish, a class of dynamical systems suitable for competitive networks called the Winnerless Competition (WLC) model has been proposed. The WLC model is appropriate for networks with inhibitory synaptic connections, which contribute to rhythmic motor activities. In this model, potential variations in a single neuron are described by the FitzHugh-Nagumo (FHN) model, whereas spiking rates of primary

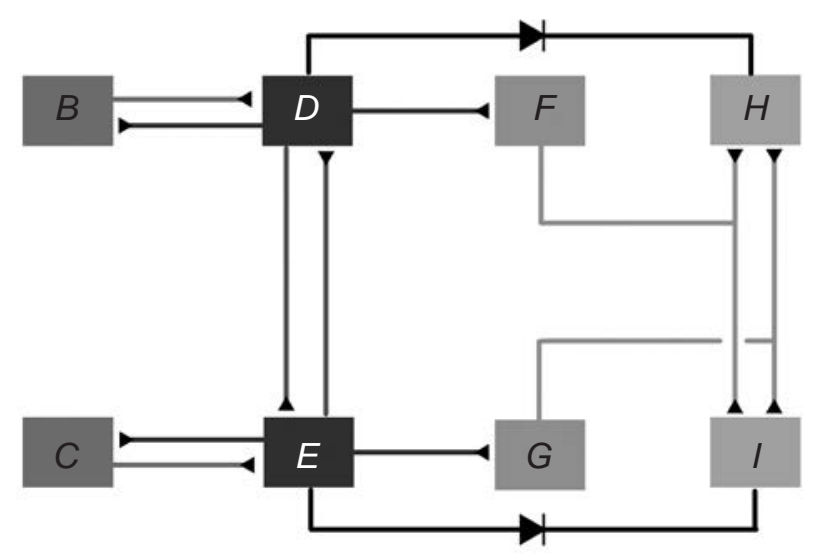

F i g. 1. Scheme of synaptic connections among HN cells.

Р и с. 1. Схема синаптичних 3'єднань між HN-клітинами. neurons are simulated with the Lotka-Volterra model. Both spiking potential and inhibition are fundamental characteristics in the WLC model, which simulate well realistic transmission of electrical signals. The WLC model is described by the following equatons:

$$
\left\{\begin{array}{l}
\tau_{1} \frac{d x_{i}(t)}{d t}=x_{i}(t)-\frac{1}{3} x_{i}^{3}(t)-y_{i}(t)-z_{i}(t)\left[x_{i}(t)-v\right]+0.35+S_{i} \\
\frac{d y_{i}(t)}{d t}=x_{i}(t)-b y_{i}(t)+a \\
\tau_{2} \frac{d z_{i}(t)}{d t}=\sum_{j} g_{j i} G\left[x_{j}(t)\right]-z_{i}(t)
\end{array}\right.
$$

Equation (1) modifies the $i_{t h}$ neuron in the corresponding network. The variable $x_{i}(t)$ denotes the membrane potential, $y_{i}(t)$ is a recovery variable, and $z_{i}(t)$ represents an inhibitory effect derived from synapses. The step function $G(x)=0$, while $x \leq 0$, and $G(x)=1$, while $x>0 ; g_{i j}$ is the strength of synaptic inhibition, and $S_{i}$ is the stimulus. Other parameters have constant values according to the corresponding model.

The WLC model simulates APs generated by neurons and denotes reciprocal inhibitions among neurons over the duration of simulation. Numerical analysis shows that the sequence of spiking and orientation of inhibition are in reverse relations, and external stimulations merely alter the start and end time, regardless of the spiking sequence. Since neurons in the WLC model possesses rich firing characteristics, this model simulates nervous systems with suppression properties extremely well and denotes spatial encoding and time encoding of AP sequences exactly. As neurons in the leech heartbeat network are connected with each other mainly through inhibitory synapses, we apply the WLC model to analyze this network below. Parameters of WLC used in our simulation are given as follows: $a=0.7, b=0.8, v_{\min }=-3, \tau_{1}=0.08$, and $\tau_{2}=3.1$.

\section{RESULTS}

Different Firing Patterns at Various Stimulations. This section illustrates various firing patterns of $\mathrm{HN}$ cells under different stimulations, including directcurrent stimulation with different DC values only, alternating-current simulation, $\mathrm{AC}=\sin (0.05 \mathrm{t} \mathrm{nA}$, only, and compound stimulation comprised of these two modes. Abundant types of firing that are similar to the phenomena shown in physiological experiments can be observed in this model, which illustrates that WLC is rather suitable for simulating the leech heartbeat network. 

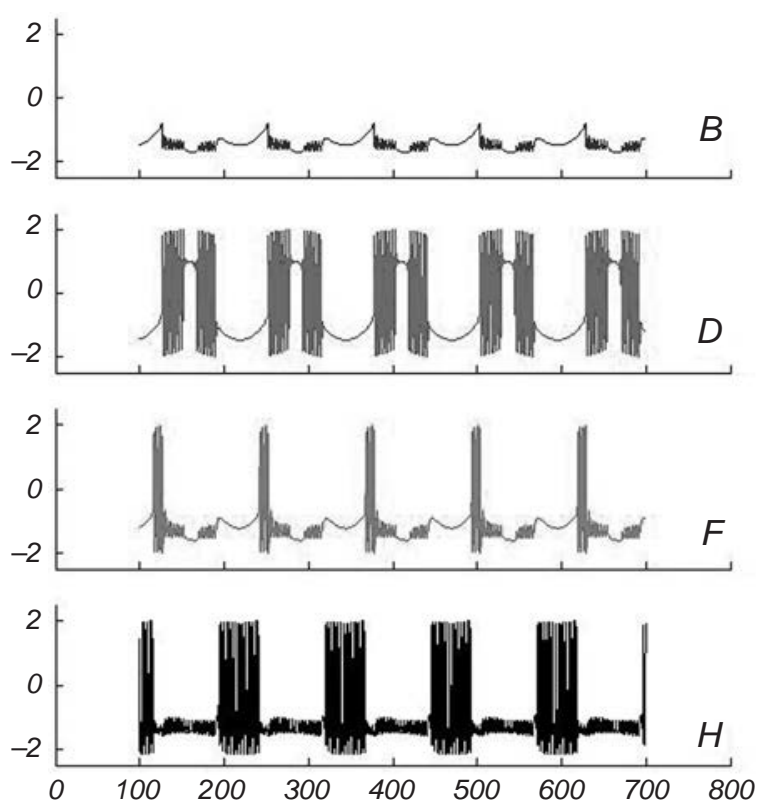
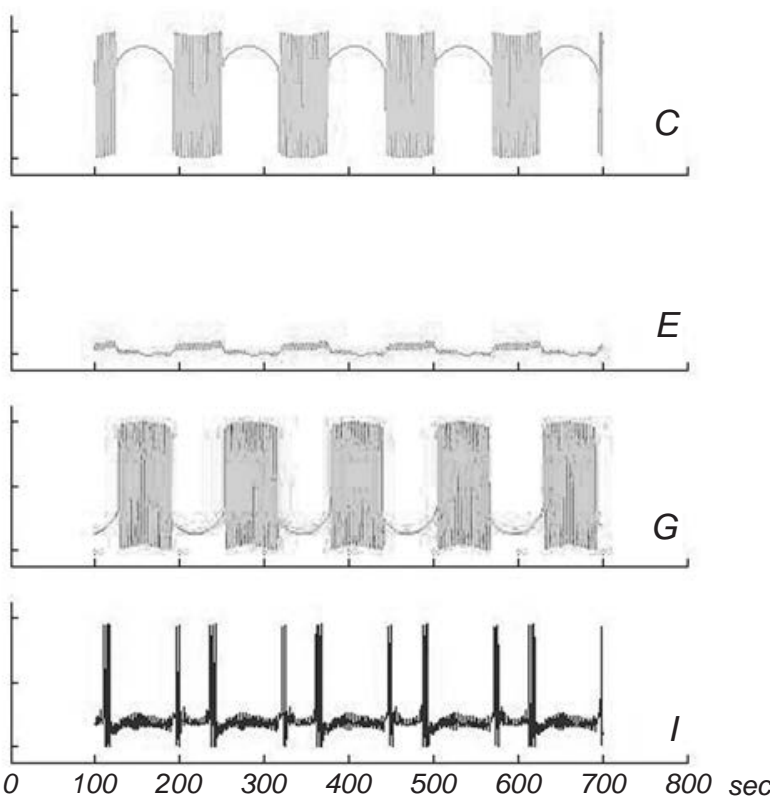

F i g. 2. Firing patterns of HN cells under compound stimulation. Neurons B-I here fire in correlative sequences and by heterogeneous patterns, just the same as neurons in a real leech, which reflect a peristaltic status. Abscissa) Time, sec; ordinate) potential, alternative units.

Р и с. 2. Патерни розрядів $\mathrm{HN}$-клітин в умовах стимуляції у змішаному режимі.

Bursts of SPs of HN cells in Fig. 2 appear when a compound-current pulse is injected into either neuron. As we know, HN cells in the leech heartbeat system play an important role in the rhythm generation for HE cells. Essentially, the rhythm generated by HN cells comes from coordinating their period of oscillations, as we see in Fig. 2. What is more important, distinct forms of HN cell bursting contribute to even more numerous abundant motoring rhythms.

Direct-current and alternating-current stimulations represent analogs of diverse input signals, e.g., different external stimuli generated by the leech's environment. We studied different neuronal spike reactions under DC and $\mathrm{AC}$ stimulations of diverse strengths. In one mode, $\mathrm{DC}$ and $\mathrm{AC}$ currents are injected into neurons separately (Fig. 3A, B). In another mode, a compound current was injected at the beginning, and then $\mathrm{DC}$ and $\mathrm{AC}$ were applied separately (Fig. 3C1, C2).

When analyzing the respective bursts, several properties can be clearly summarized. In the first instance, when comparing distinct firing patterns under DC and AC stimulations, we can observe that synchronization and periodical bursts emerge more easily under AC stimulation, while bursts under DC action appear with certain irregularity. Furthermore, it seems that AC stimulation is regarded as an analog of the action of relatively moderate environmental factors, while DC stimulation mimics a rather severe action. Yet, neither of these two firing patterns matches well with the peristaltic status of HN cells, which is simulated more closely with compound stimulations, as shown in Fig. 2. Hence, AC plays an important role in the periodical generation, while DC harasses the synchronization to bring a more realistic busting rhythm. Moreover, in Fig. $3 \mathrm{C} 1$ and $\mathrm{C} 2$, compound injections of $\mathrm{DC}$ and $\mathrm{AC}$ are given at first; then, after one of them is stopped, both firing patterns regress to the condition obtained when one kind of current is injected. This phenomenon not only clearly clarifies the independence between the DC and AC effects, but reflects well the robustness of the leech heartbeat system when facing dramatic changes in the external environment.

As was shown above, different firing patterns appear when DC and AC currents are injected into $\mathrm{HN}$ cells separately; this also emerges when compound currents with distinct parameters of AC are injected (Fig. 4). For interneuron D, along with the frequency $w$ increasing and other parameters being stable, the number of spikes per period and the duration of each period decrease. As for the amplitude $A$, the number of spikes per period decreases when $A$ increases, while the duration of each period remains stable regardless of changes in the amplitude. In other words, the amplitude of $\mathrm{AC}$ alters the number of spikes per 


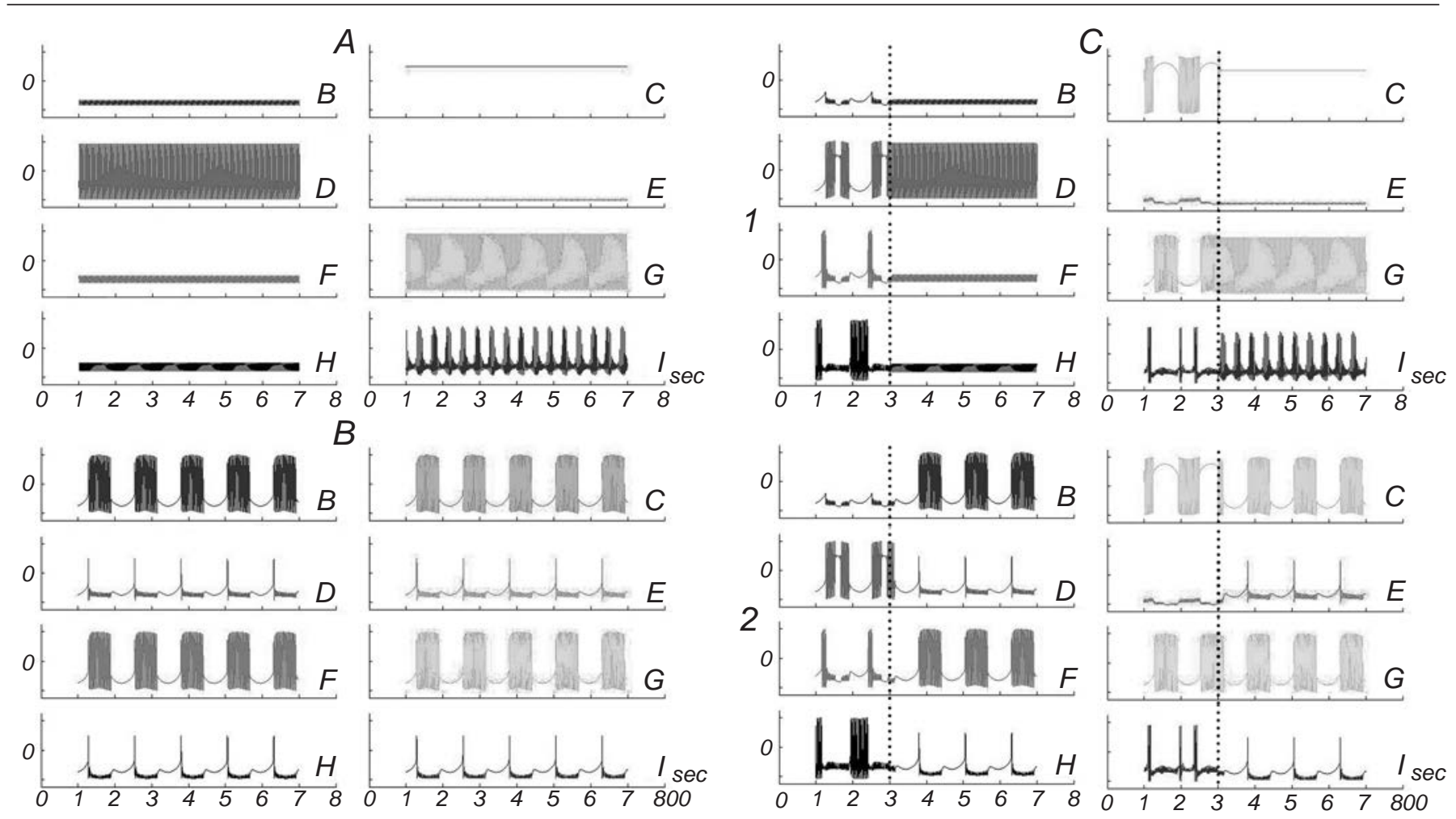

F i g. 3. Firing patterns of HN cells under different current stimulations. A) DC stimulation only; B) AC stimulation only; C1) compound stimulation is exerted on $\mathrm{HN}$ cells in the beginning, and then DC is applied alone (after a black dashed line); C2) mixed stimulation is exerted on $\mathrm{HN}$ cells at the beginning, and then $\mathrm{AC}$ acts alone after a black dashed line.

Р и с. 3. Патерни розрядів HN-клітин при різних варіантах струмової стимуляції.
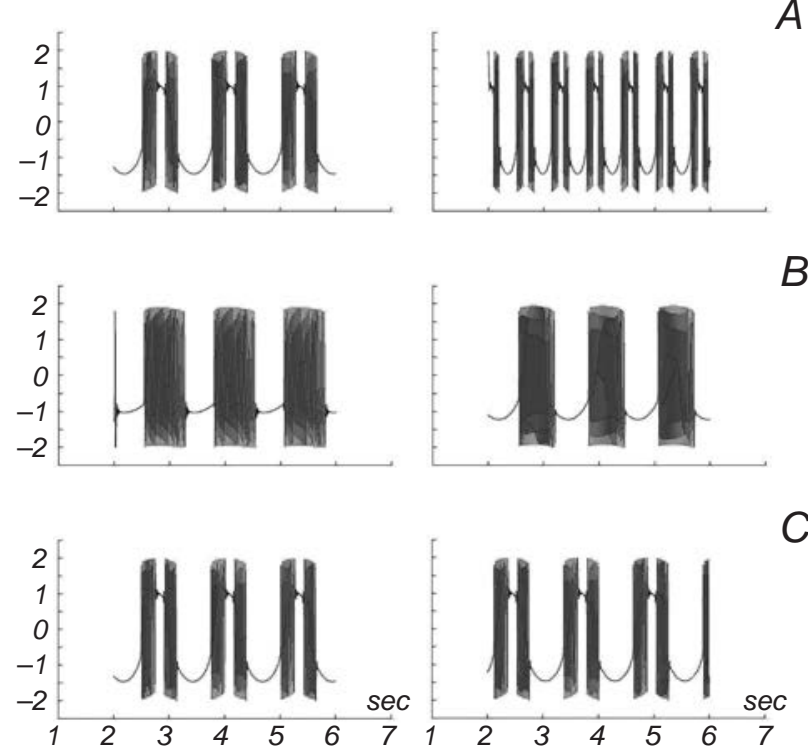

$\mathrm{B}$

C
A
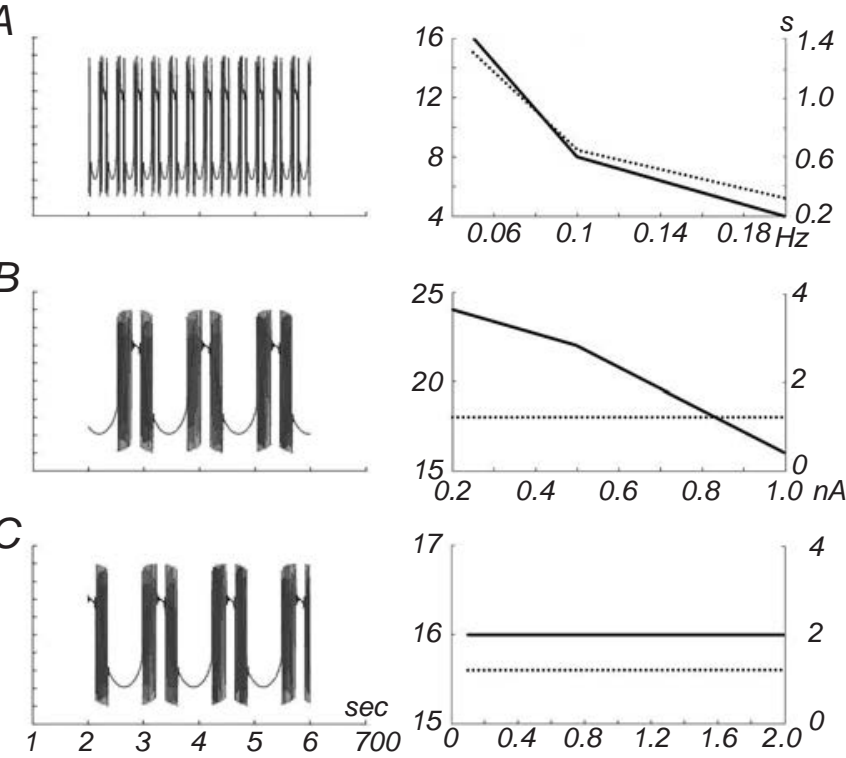

F i g. 4. Different reactions of interneuron $D$ in response to various changes in the external stimuli. A) Reactions when ambient conditions change with a distinct rate, namely, the frequency $w=0.05, w=0.1$, and $w=0.2 ; \mathrm{B})$ conditions change with a distinct size; the amplitude $A=0.2, A=0.5$, and $A=1 ; \mathrm{C})$ they change with a distinct start time; phase $P h i=0.1, P h i=1$, and $P h i=2$.

P и с. 4. Специфіка реакції інтернейрона D при різних змінах зовнішніх стимулів. 
period, without affecting the period duration. As to the phase $P h i$, the firing pattern does not change at all, independently of how Phi changes. Hence, the $\mathrm{AC}$ frequency influences both the number of spikes per period and the duration of each period, while the amplitude of this current influences only the former one, and the phase does not affect either.

According to these results, we may suppose that the rate of the external environmental changes has the greatest influence on the leech with respect to both intensity and duration of the reaction, while the sharpness of changes in the ambient conditions varies only the reaction intensity; when the environment changes, it does not affect either.

Synchronization in the Network. Neuronal synchronization is quite momentous in nature. In the leech heartbeat system, HN cells inhibit HE cells rhythmically. This action regulates blood vessels, namely HN cells modulate the rhythm of the leech heartbeat. Hence, synchronization of $\mathrm{HN}$ cells deserves to be discussed carefully. Here, we describe synchronization within the network through a pattern shown in Fig. 5A. When we give an injection, neurons in this network display periodical changes.

According to a series of the experiments on medical leeches, only one of the switch HN cells (F and G) will completely burst in any heartbeat cycle, while another one will not, no matter whether or not it was rhythmically inhibited by the beat-timing oscillator [12]. In accordance with these experiments, bursting in our study also met this property. As there is only one switch interneuron active at one time, an asymmetry occurs between the two sides of heart interneurons. Interneurons $\mathrm{D}, \mathrm{E}, \mathrm{H}$, and $\mathrm{I}$ are active mainly in-phase with the activity of a switch interneuron's side (in this case, relations of $\mathrm{E}$ and I are not clear in this pattern but quite obvious in Fig. 2). Interneurons $\mathrm{H}$ and $\mathrm{I}$ lead units $\mathrm{D}$ and $\mathrm{E}$ in-phase with the silent interneuron's side $(\mathrm{H}$ and $\mathrm{D}$, interneuron $\mathrm{H}$ leads $\mathrm{D}$ in phase) [13]. Under these circumstances, clear differences between the two sides of interneurons indicate the peristaltic mode in the leech.

Besides the pattern, a phase difference between spike timings of two neurons is also an ideal indicator to describe different states of synchronization, including in-phase synchronization when two oscillators have no phase difference, out-of-phase synchronization when the phase difference remains constant, and desynchronization when the phase difference is distributed irregularly. Hence, the scatter of the phase differences can help us to clearly distinguish different states of synchronization. The phase difference if defined as:

$$
\Delta \varphi=2 \pi \frac{\tau-t_{1}}{t_{2}-t_{1}}, t_{1}<\tau \leq t_{2},
$$

where $t_{1}$ and $t_{2}$ represent the adjacent release times of one neuron, and $\tau$ represents the spike time of another.

In Fig. 5B, we take variation of the phase differences as a function of the coupled strength, which shows that phase differences between corresponding interneurons alter from a disordered state to an ordered one and

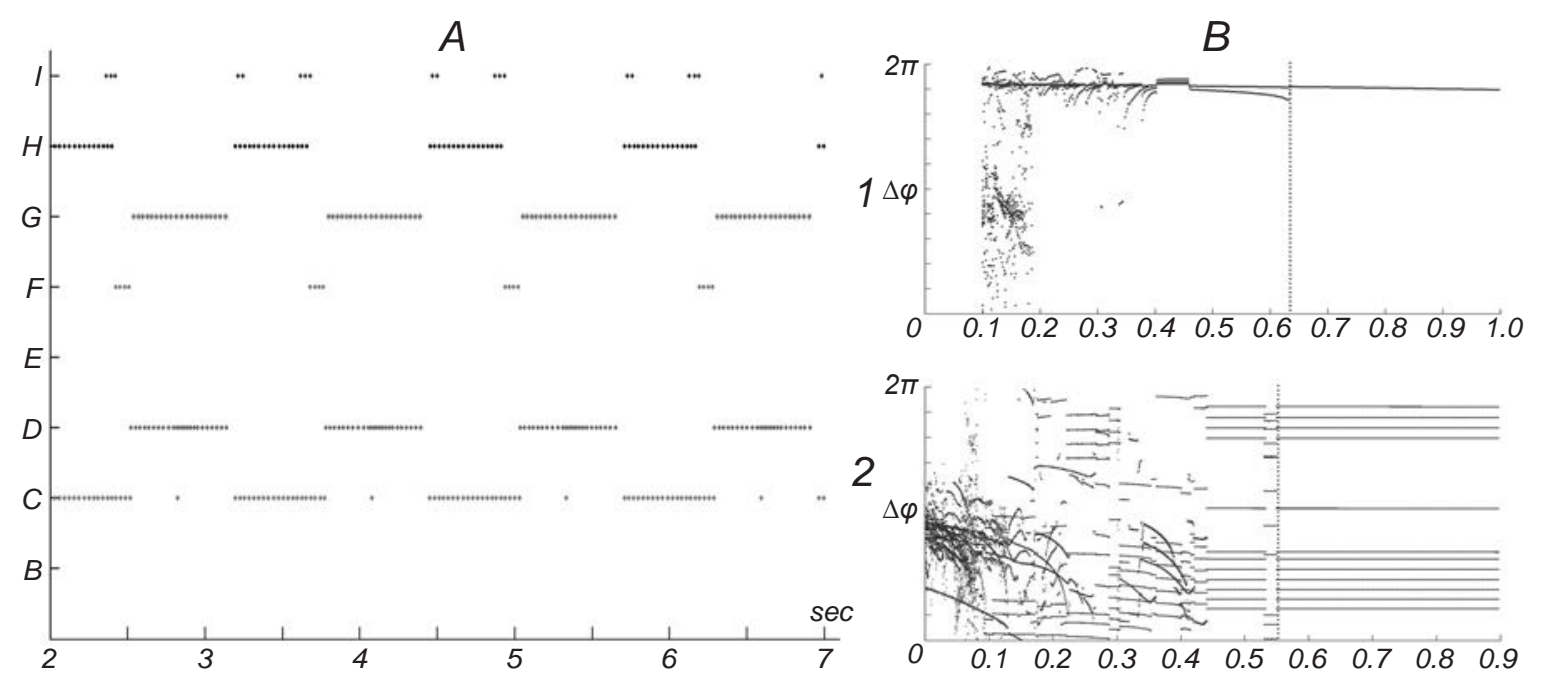

F i g. 5. Integral synchronization of spike firing in the network. A) Discharge patterns under given compound stimulation; B) phase differences between interneurons $\mathrm{C}$ and $\mathrm{H}$ (1) and those between interneurons G and $\mathrm{H}(2)$ are plotted $v s$ coupled strength.

Р и с. 5. Інтегральна синхронізація імпульсної активності в мережі. 
increase with the coupling strength. According to Fig. 5B, 1, interneurons $\mathrm{C}$ and $\mathrm{H}$ are irrelevant when the interconnected strength among neurons is weak. When the strength is enhanced to a certain degree, $\mathrm{C}$ and $\mathrm{H}$ come into a state in which they are almost in-phase, which is consistent with the result in Fig. 5A. Phase differences of interneurons $\mathrm{G}$ and $\mathrm{H}$ in Fig. 5B, 2 declare that the states of these two neurons change from desynchronization into out-of-phase synchronization along with increase in the coupling strength. Furthermore, according to the positions of the two dashed lines in Fig. 5B, we found that neurons in the leech heartbeat network reach a relatively stable state at not the absolutely same time but, nonetheless, nearly simultaneously, since the difference of the positions of these two lines is tiny.

Interspike Intervals and Maximum of APs. In this section, responses of HN cells to changes in the external environment having different frequencies are examined using varieties of the ISIs and maximum of APs vs AC frequency. Since HN cells are more or less similar to each other in their spike firing, we choose two interneurons $B$ and $G$ from the group of $\mathrm{HN}$ cells to illustrate some characteristics in firing of interneurons in the leech heartbeat system.

Fig. 6A shows changes of the ISIs of interneuron $\mathrm{B}$ depending on the frequency $w$ of the stimulating current, for $\mathrm{AC}=\sin (w \mathrm{t})$. While $w=1.8 \mathrm{~Hz}$, interneuron $\mathrm{B}$ generated stable spiking. The firing pattern of interneuron B changed from such spiking to bursting approximately at $w=1.9 \mathrm{~Hz}$ along with a bifurcation of ISIs. The difference between the longest ISI and the short one became larger at first and then decreased after $w=2.3 \mathrm{~Hz}$ (approximately), till a chaotic pattern appeared at $w=2.4 \mathrm{~Hz}$. When the chaotic region terminated, two separate ISIs still existed, which showed cross-changing with the frequency till $w=3.1 \mathrm{~Hz}$ (approximately). At $w=3.1 \mathrm{~Hz}$, another chaotic area appeared; after this region, the firing pattern of interneuron B altered from bursting to spiking in reverse.

Fig. 6B shows the maximum of AP of interneuron $\mathrm{G}$ changing with the frequency of the current stimuli, for $\mathrm{AC}=\sin (w \mathrm{t})$. The maximum possesses a single value when $w=1.8 \mathrm{~Hz}$, but this maximum turns into a couple of values after the frequency $w$ increases to approximately $1.9 \mathrm{~Hz}$. The difference between the large maximum and the little one becomes larger at first and then decreases after $w=2.3 \mathrm{~Hz}$ (approximately), till a chaotic state appears when $w=2.4 \mathrm{~Hz}$. After passing through the chaotic region, the maximum possesses three values, which are different from changes in the ISIs mentioned above.

Generally, there will be period-doubling bifurcation on the chart of ISIs or maximum of AP against frequency. Nevertheless, period-doubling bifurcation did not appear in our experiment. Instead, we observed bifurcations that are seen in Fig. 6, which haven't been found before.

Mixed-Mode Oscillations. A dynamical system is called an oscillator when it turns into the same or almost the same state over and over again. When the system switches between fast and slow motions, mixed-mode oscillations (MMOs) occur [14]. Such oscillations arise in various systems that possess chemical and biological rhythms in nature, in particular in the leech heartbeat networks modeled using WLC in our study. The Belouzov-Zhabotinsky (BZ) reaction has been the model that is most often studied since it was discovered in the 1970s. In 2005, Wechselberger, Brons, et al. [15-17] performed a detailed study of
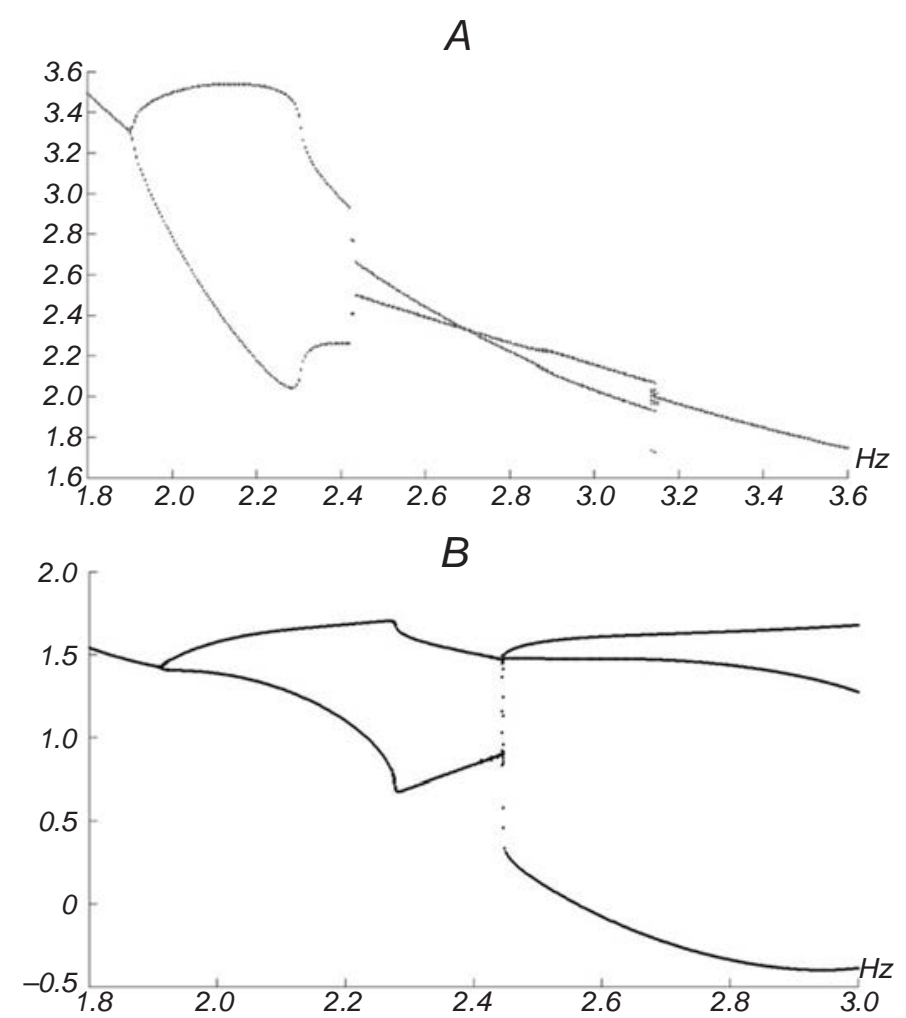

F i g. 6. Interspike intervals (ISIS) of interneuron B plotted $v s$ stimulus frequency $w(\mathrm{~A})$ and maximum of the membrane potential $V_{\max }$ of interneuron $\mathrm{G}$ plotted $v s$ stimulation frequency $w$ (B). Parameters are the following: $a=0.2, b=1.0, v_{\min }=-3, \tau_{1}=0.6$, and $\tau_{2}=3.1$.

P и с. 6. Залежність міжімпульсних інтервалів у нейрона В від частоти стимуляції $(A)$ і аналогічна залежність максимуму мембранного потенціалу $V_{\max }$ у нейроні G. 
MMOs and generation of a canard phenomenon. The phenomenon of MMOs in the Hodgkin-Huxley (HH) model was researched by Rubin et al. [18, 19].

In this section, we studied the effects of parameters
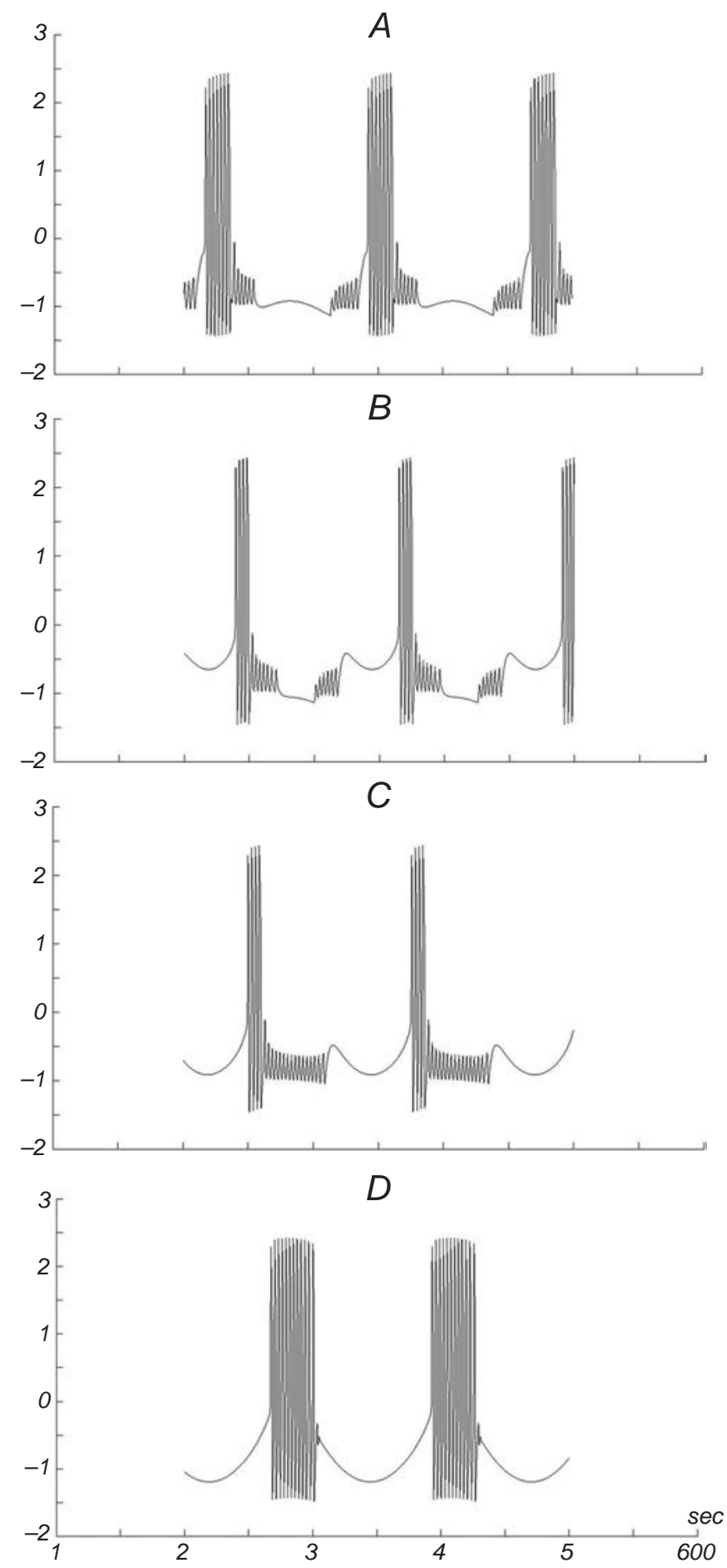

F i g. 7. Different firing patterns of interneuron $F$ at changes in its recovery ability.

Р и с. 7. Різні патерни розряду інтернейрона $\mathrm{F}$ при змінах його здатності до відновлення. in the WLC model on the release mode of interneurons. Through a series of attempts, MMOs appeared when we changed the recovery variable $a$, which represents the ability of the neuron to restore its state. Fig. 7 shows various firing patterns of interneuron $\mathrm{F}$ along with recovery variables of different sizes. While $a=0.1$, as is shown in Fig. 7A, there were bursting patterns of a large amplitude along with small ones on both sides, while this firing pattern changes when $a=0.6$ in Fig. 7B. In Fig. 7C, only one bursting of a small amplitude accompanies the large one at $a=1.0$. In Fig. 7D at $a=1.6$, small-amplitude bursting disappeared, and only large-amplitude bursting remained. Such clear phenomena of MMOs in the leech heartbeat system modeled by WLC have been first observed.

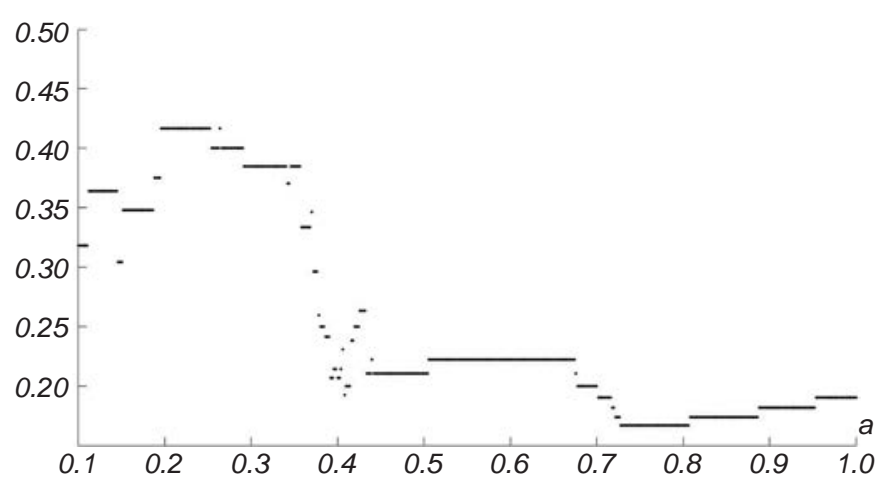

F i g. 8. Firing number of interneuron F plotted $v s$ parameter $a$.

P и с. 8. Залежність кількості потенціалів дії, генерованих інтернейроном $\mathrm{F}$, від параметра $a$.

To describe the characteristics of MMOs, a firing number is defined as $L /(L+S)$ [20], where $L$ is the number of bursting periods with a large amplitude, and $S$ is the number of bursting periods with a low amplitude per period. As is shown in Fig. 8, this firing number looks like a piecewise function along with recovery of the variable $a$, which indicates that MMOs will stay constant in a period of time. When changing $a$ from 0.1 to 1.0 , the firing number decreased on the whole, namely the ratio of bursting with a large amplitude decreased, as we can see in Fig. 8. Gaps between these steps indicate that the corresponding mix-mode behaviors do not exist.

\section{DISCUSSION}

In our study, we have used the WLC model to analyze different firing patterns of interneurons corresponding to distinct external environments of the animal (leech). Our results demonstrate that different types 
of the external environment produce diverse effects on $\mathrm{HN}$ cells. More specifically, AC is crucial in the period generation, while DC disturbs the synchronization to bring a busting rhythm similar to that in the reality. As for how rapidly, how sharply, and when the external environment changes, these modifications exert diverse effects upon the intensity and duration of the leech's reaction. Moreover, a fairly complex synchronization system in the leech heartbeat system depends strongly on the connection strength, which can entirely destroy the synchronization when the latter becomes rather weak. Finally, MMOs appear when recovery abilities of the neuron change, which leads to various spiking modes of HN cells. In these numerical results, HN cells exhibit excellent characteristics in the conventional manner, which indicates that the WLC model performs well in modeling the leech heartbeat system.

In conclusion, interneurons in this heartbeat system exhibit various reactions when faced with different types of the external environment. Furthermore, inherent characteristics, i.e., the connection strength and recovery ability, also have an important impact on the release mode of the examined neurons.

Acknowledgment. The authors would like to acknowledge the generous support by the National Natural Science Foundation of China (Grant No. 11172103).

Since our study dealt exclusively with computer modeling, it was not necessary to confirm its compliance with the statements of the International Convention (Strasbourg, 1986, and later versions).

The authors, N. S. Ju, S. Q. Liu, B. Lu and X. F. Jiang, confirm that they have no conflict of interest with any organization or person that may be related to this study; there was also no conflict of interest in interrelations between the authors.

Н. Ш. Джу ${ }^{1}$, Ш. К. Лю

\section{ПАТЕРНИ РОЗРЯДІВ ІНТЕРНЕЙРОНІВ ГЕНЕРАТОРА СЕРЦЕВОГО РИТМУ П'ЯВКИ В УМОВАХ ДІЇ ЕЛЕКТРИЧНОЇ СТИМУЛЯЦІЇ: МОДЕЛЬНЕ ДОСЛІДЖЕННЯ}

\author{
1 Південнокитайський технологічний університет, Ганчжоу \\ (Китай). \\ P е 3 ю м е
}

Інтернейрони генератора серцевого ритму (HN-нейрони) п'явки, зв'язані гальмівними синапсами, піддавалися мо- делюванню 3 використанням декількох модифікованих моделей, основаних на рівняннях Ходжкіна - Хакслі, проте адекватні характеристики $\mathrm{HN}$-клітин було важко відтворити через складність таких моделей. Для моделювання мереж, до яких входять HN-клітини, більш придатною є так звана Winnerless Competition-модель, розроблена для симулювання мереж із нейронів, які поєднані гальмівними зв'язками. Ми досліджували різни патерни розрядів, генерованих такою моделлю, в умовах прикладання різних струмових стимулів, імітуючих зміни в середовищі мешкання п'явки. Реєстрація частот розрядів, їх синхронізації, міжімпульсних інтервалів, максимумів потенціалів дії (ПД), а також застосування теорії мішаного режиму осциляцій дозволило дослідити різні властивості патернів розрядів НN-клітин. Згідно з результатами комп'ютерного аналізу, стимуляції постійним та змінним струмами, як виявилося, відіграють різну роль у модуляції серцевого ритму п'явки; зовнішні стимули можуть впливати на інтенсивність та тривалість реакції мережі, змінюючи як частоту, так і амплітуду ПД. Окрім того, зміни в здатності нейронів до відновлення можуть призводити до різних варіантів розрядів $\mathrm{HN}$-клітин. Поєднання фізіологічних експериментів на п'явках та модельного комп'ютерного аналізу дозволяє дійти глибшого розуміння, яким чином $\mathrm{HN}$-клітини координують свою активність у перебігу формування ритму в системі керування скороченнями «серця» у цієї тварини.

\section{REFERENCES}

1. I. B. Levitan and L. K. Kaczmarek, The Neuron: Cell and Molecular Biology, Oxford Univ. Press, Oxford (2001).

2. R. L. Calabrese, "The neural control of alternate heartbeat coordination states in the leech, Hirudo medicinalis," J. Comp. Physiol., 122, 111-143 (1977).

3. F. Nadim, O. H. Olsen, E. De. Schutter, and R. L. Calabrese, "Modeling the leech heartbeat elemental oscillator 1. Interactions of intrinsic and synaptic currents," J. Comput. Neurosci., 2, 215-235(1995).

4. O. H. Olsen and R. L. Calabrese, "Activation of intrinsic and synaptic currents in leech heart interneurons by realistic waveforms," J. Neurosci., 16, 4958-4970 (1996).

5. E. A. Arbas and R. L. Calabrese, "Slow oscillations of membrane potential in interneurons that control heartbeat in the medicinal leech," J. Neurosci., 7, 3953-3960 (1987).

6. J. D. Angstadt and R. L. Calabrese, "A hyperpolarizationactivated inward current in heart interneurons of the medicinal leech," J. Neurosci., 9, 2846-2857 (1989).

7. A. Wenning, G. S. Cymbalyuk, and R. L. Calabrese, "Heartbeat control in leeches. I. Constriction pattern and neural modulation of blood pressure in intact animals," $J$. Neurophysiol., 91, 382-396 (2004).

8. J. Kristan, B. William, R. L. Calabrese, and W. O. Friesen, "Neuronal control of leech behavior," Prog. Neurobiol., 76, 279-327 (2005).

9. A. A. Hill, M. A. Masino, and R. L. Calabrese, "Model of intersegmental coordination in the leech heartbeat neuronal network," J. Neurophysiol., 87, 1586-1602 (2002).

10. A. R. Maranto and R. L. Calabrese, "Neural control of the hearts in the leech, Hirudo medicinalis," J. Comp. Physiol., 
154, 367-380 (1984).

11. M. Rabinovich, A. Volkovskii, P. Lecanda, et al., "Dynamical encoding by networks of competing neuron groups: Winnerless Competition," Phys. Rev. Lett., 87, No 6, 068102 (2001).

12. S. Gramoll, J. Schmidt, and R. L. Calabrese, "Switching in the activity state of an interneuron that controls coordination of the hearts in the medicinal leech (Hirudo medicinalis)," J. Exp. Biol., 186, 157-171 (1994).

13. G. Shepherd and S. Grillner, Handbook of Brain Microcircuits, Oxford Univ. Press, Oxford (2010).

14. A. Milik, P. Szmolyan, H. Loeffelmann, and E. Groeller, "Geometry of mixed-mode oscillations in the 3d autocatalator," Int. J. Bif. Chaos., 8, 505-519 (1998).

15. E. Benoit, "Systèmes lents-rapides dans $R 3$ et leurs canards," Astrisque, 109, 159-191 (1983).
16. M. Brøns, M. Krupa, and M. Wechselberger, "Mixed mode oscillations due to the generalized canard phenomenon," Fields Inst. Commun., 49, 39-63 (2006).

17. M. Wechselberger, "Existence and bifurcation of canards in R3in the case of a folded node," SIAM J. Appl. Dyn. Syst., 4, 101-139 (2005).

18. J. Rubin and M. Wechselberger, "Giant squid-hidden canard: the 3D geometry of the Hodgkin-Huxley model," Biol. Cybern., 97, 5-32 (2007).

19. J. Rubin and M. Wechselberger, "The selection of mixedmode oscillations in a Hodgkin-Huxley model with multiple timescales," CHAOS, 18, No1, 015105 (2008).

20. V. Petrov, S. K. Scott, and K. Showalter, "Mixed-mode oscillations in chemical systems," J. Chem. Phys., 97, 61916198 (1992). 